\title{
Bullying Amongst Parents and Teachers at an American International School: Informing School Development and Policy
}

\author{
Paul James ${ }^{1 *}$ \\ ${ }^{1 *}$ Graduate School, Education and Health Care Studies, Bangkok University, Bangkok, \\ Thailand. Tel: +662350 3500 E-mail: paul.j@bu.ac.th
}

Received: July 25, 2012 Accepted: August 26, 2012 Published: September 20, 2012

doi:10.5296/ije.v4i3.2273 URL: http://dx.doi.org/10.5296/ije.v4i3.2273

\begin{abstract}
This paper has sought to explore the everyday experiences of parent-teacher bullying within a purposefully selected American International school.

The paper utilises a qualitative approach targeting an American International school using a small semi-structured questionnaire creating a focused element of context and flexibility. 12 parents were randomly chosen from 35 that were available and willing to share their needs and experiences and the interview method was used as the data-collecting vehicle. This paper addresses issues raised from parent's experiences of bullying.

The 3 developed research questions were mapped to 6 major themes, and were supported by 13 sub-themes. The presented qualitative data outcomes highlight the various experiences, perspectives and challenges that parent's perceive they face.

The impact of this research suggests that the perceived complexities of dealing with bullying between parents and teachers may be mitigated with appropriate training and specialist guidance leading to the application of 8 outcomes.
\end{abstract}

Keywords: Bullying, School, International, Parents, Mitigation Strategies 


\section{Introduction}

For many schools, bullying in all its forms is exacted through a backdrop of ordinary school socio-structural lapses that only small proportions of the school inhabitants see, hear or feel its violent backdraft which appear to have a negative impact on the physi120cal and mental health of those involved (Fleming and Jacobsen, 2009) often emanating through stress (Cowie and Oztug, 2008). However, difficulties remain as to how to estimate or measure effectively the prevalence of bullying in schools (Espelage and Swearer 2003) or its perceived severity (Delfabbro et al., 2006). Further, many researchers see bullying as a large pervasive problem in schools (Berthold and Hoover, 2000; Nansel et al. 2001) reflecting the theory of social dominance (Hawley, 1999) or a personality trait (Johns, Livson, and Peskin, 2003). For a small proportion of students/teachers and parents in school, across nations (Harel-Fisch et al., 2010) student life continuously revolves around the escape from a bully or the act of intimidation by bullies. Researchers often identify bullying as a behaviour (Nansel et al. 2001) defined as direct - physical (hitting), verbal (threats, laughing), relational (Bauman and Del Rio, 2006) (manipulation of interpersonal relationships) and indirect cyber-bullying (Craig, Pepler and Blais, 2007) (messaging on-line for the purpose of threatening or harassing an individual). Bullying can also be described as groups Vs. individuals or visa versa; and individuals Vs. individuals. Fundamental to the bullying tactic is the intentional act of aggression through the presumption of power. Bully's persecute because they believe they have an inalienable right to do it reflects the perceived power differential (Craig and Pepler, 2003). This introduces the first research question: In what ways and forms is teacher-parent bullying characterised at this school?

Teacher involvement in bullying most often occurs through incidents between students and focused mainly on physical bullying (Ellis and Shute, 2007). The variance of teacher intervention appears to be related to the teacher's perception of the severity of the bullying (Maunder et al., 2010) - often because of a single episode - but was less likely to intervene in other forms of bullying (Yoon \& Kerber, 2003). However, little research has been conducted of bullying between parents and teachers - especially in a private international school. Boulton (2008) suggested that a common reason why parents can feel unsafe in school is through teacher bullying as they had an upper-hand in terms of work-related power. Parent to parent bullying also occurs as any repeated aggressive behaviour or action that is carried out with the intention to hurt, damage or distress another parent (Olweus, 1993) and that although many children feel the effects of bullying not all parents see or feel peer-parent-teacher bullying (Rivers, 2001). However, teacher-parent bullying appears to be on the increase as competition in schools for resources increase as well as the lack of teacher/management support (Flaspohler, et al., 2009). This introduces the second research question: How does bullying between teachers and parents affect other stakeholders in the school?

Most, if not all school-wide anti-bullying policies and practices are assumed to be directed at students - although this is obviously insufficient (Smith, et al., 2008). There is no research that shows a policy change incorporating parent-teacher bullying.

Work on mediating bullying formed through mediating processing involving the effects 
of bullying have been studied (Seeds, Harkness, Quilty, and Harkness, 2010). Whilst this suggests that bullying has reduced through closer supervision by teachers, bullying still afflicts the playground where there is no supervision - as in after-school incidents (Whitney and Smith, 1993). However, whilst the importance of implementing (Cowie and Jennifer, 2007; Sullivan, 2000) whole-school bullying prevention (Bauman 2008) has had little effect on the total reduction of bullying, as in most cases only a partial success of interventions (Smith, Pepler, and Rigby, 2004) have been reported. This would involve working closely with parents to address bullying in all its forms. However, Limper (2000) emphasised the benefits of parents involvement in reducing bullying results in better cooperation with teachers - as teachers appear not to be very effective when dealing with bullying (Fekkes, Pijpers, \& Verloove-Vanhorick, 2005); often lack the personal will to stop it (Smith \& Shu, 2002); or ignore the bullying episode totally (Bauman \& Del Rio, 2006) resulting in a culture of silence (Smith \& Shu, 2002). Where parents have been involved in bullying research, they often involved family characteristics (Baldry and Farrington, 2000); as agents of the victimised child (Nordhagen, Nielsen, Stigum and Kohler, 2005); through parental support (Wang, Iannotti and Nansel (2009); teacher support (Conners-Burrow et al., 2009); parent's level of understanding of the nature bullying ((Mishna and Alaggia, 2005); conducted at the parents home (Barboza et al., 2009); and involved gender differences (Craig and Pepler, 1997). Most research however, focuses on the student-peer bullying arena. Future research should include exploration of the perspectives of parents of children who bully (Sawyer et al., 2011). Currently, few studies have been conducted from the parent's perspective. However, little research has been carried out in the area of parent-teacher bullying ecological environment (Germain and Bloom, 1999) and this is the focus for this paper. This introduces the third research question: What policies need to developed and implemented to reduce bullying between teachers and parents?

\section{Methodology}

Most researchers on bullying - focusing on students - have employed quantitative methodologies using large samples (Bosworth, Espelage, and Simon, 1999). For example, only $10 \%$ of bullying studies reported between 2000 and 2004 utilised a qualitative methodology (Powell et al., 2008), Consequently, to develop a much broader, and deeper approach surrounding the issues generated within the school context and to consider more implicitly the issues and questions raised, this empirical groundwork utilised an interpretive approach (Walsh, White, and Young, 2008). This was an attempt to understand the very personal perceptions of bullying experiences (Torrance, 2000) between teacher and parent. Parents were equally considered specialist knowledge agents and actors (Benn et al., 2008) as their opinions and experiences (Gilgun and Abrams, 2002) influenced the effectiveness of school anti-bullying practices, and the development and application of anti-bullying practices policy in the school. The research used a semi-structured interview conducted with parents, which provided an appropriate element of context (Carroll and Rothe 2010) and flexibility (Cassell and Symon, 2004) and this was further aided by applying an inductive/theory building approach (Glaser and Strauss, 1967). Given the lack of appropriately focused research in this area, this methodology is seen as suitable for creating contextual data for the 
purpose of forming richer theory development (Cayla and Eckhardt, 2007). The population for this study was made up of 35 parents - chosen through applying the approach of a targeted population of interest (Carman, 1990) and this reflected the criteria of theoretical purpose, relevance and appropriateness (Glaser and Strauss, 1967). Further, using Glaser's (2004) sampling processes, and also guided by Garbarino and deLara (2002), a total of 12 parents were thus determined as the resultant sample frame, which could also be considered convenience sampling according to Harrel and Fors (1992).

Each interview was audio recorded for future analysis. Interviews were conducted in English and took approximately one hour. All interviews were recorded digitally after gaining explicit permission, and were later transcribed verbatim using NVivo software. The conduct of the interviews follows a similar process used by Gray and Wilcox (1995), with each individual group being asked the same set of questions - modified through ancillary questioning (probes and follow-ups) in the same way as Balshem (1991). To increase the reliability of the data, the actual transcription was returned to each respondent - via e-mail -for comment, correction, addition or deletion and return, which followed the process of validated referral (Reeves and Harper, 1981). Whole-process validity was achieved as the respondents were considered widely knowledgeable of the context and content associated with the research orientation (Tull and Hawkins, 1990).

Written consent was obtained from all respondents prior to any interviews being undertaken - except that a separate negotiation was made with the head-teacher in order to allow the interviews to be carried out on school premises, just before their child's pickup at the end of the school day. Each interview was initially manually interrogated and coded initially using the Acrobat software according to sub-themes that 'surfaced' from the interview dialogue - using a form of open-coding derived from Glaser (1992a); and Straus and Corbin (1990). This treatment was also reinforced and extended through the use of thematic analysis conducted using the NVivo 9 - qualitative software package (Walsh, White and Young, 2008). Each interview was treated and coded independently. In this way, no portion of any interview dialogue was left uncoded and the overall outcome represented the shared respondents views and perspectives through an evolving coding-sequence (Buston, 1999). Various themes were sensed from the use of the software packages, as well as from the initial manual-coding attempts. This dual form of interrogation was an attempt to increase the validity of the choice of both key themes and sub-themes through a triangulation process. NVivo 9 was further used to explore these sub-themes by helping to pull together each of these sub-themes from all the interviews (Harwood and Garry, 2003). In this way, it was possible to capture each respondent's comments across transcripts (Riessman, 1993) on each supported sub-theme and place them together for further consideration and analysis.

\section{Findings}

The research questions were mapped to the 6 Main themes, which generated 13 sub-themes, as indicated in Table 1 - Research Questions and Major and Sub-Themes. The major themes are further discussed below and the total number of references for these themes are also indicated in Table 1. 


\section{Macrothink}

The outcomes are stated below where the discussion focuses on the research questions, main themes, sub-theme elements within each key theme and the breadth of respondent illustrations/extractions as used in the reporting of this research (numbers do not infer relative importance) are presented in Table 1, below. The discussion format used in this paper reflects the respondent's voice through a streamlined and articulated approach for reporting. Consequently, the style adopted for reporting and illustrating the data is greatly influenced by Gonzalez, (2008) and also Daniels et al. (2007) and is discussed below, focusing on the raised research questions and the resultant main themes.

Table 1: Sub-themes discussed in this paper (other sub-themes are considered of less persuasive significance)

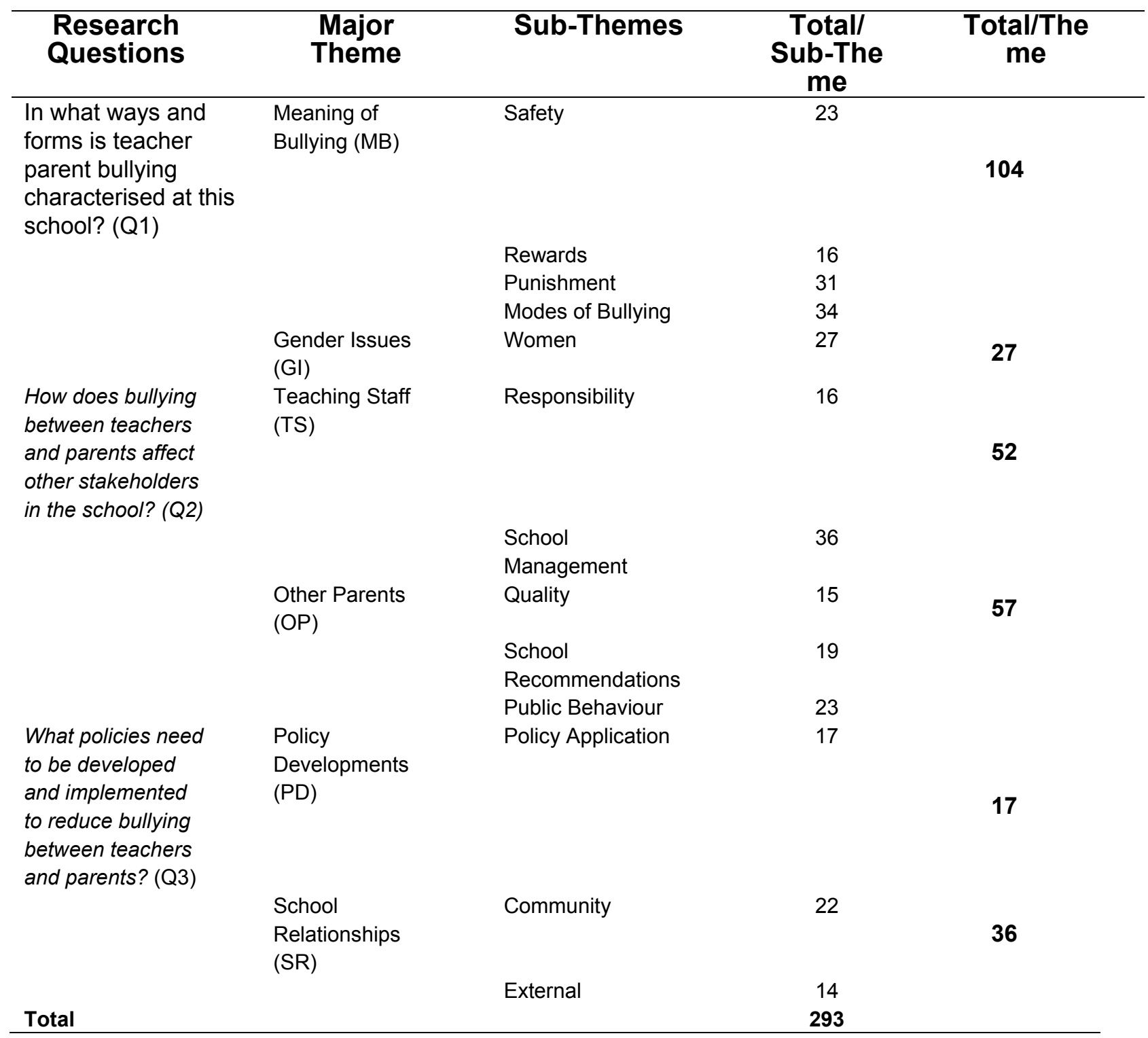




\subsection{Major Theme Discussion}

The following discussion uses the 6 major-themes (contained in Table 1, above) as its basis and consequent sub-themes in terms of where the sub-theme would appear to have most influence.

First research question: In what ways and forms is teacher-parent bullying characterised at this school?

\subsubsection{What Bullying Means to Parents}

Parents appeared to have different views of what constituted bullying between parents and teachers. As one respondent (P4) indicated ...I expect this school to be safe for everyone. It isn't at the moment. You have to be very careful with who you talk to. Some parents are just plain nasty. Another respondent (P3) suggested that ...bullying means to me that someone -another parent - looks for you. It's like being back at school when I was young. I'm pulling out of this school at the end of the semester because of this. This suggests that bullying is something that parents recognise from their past.

Bullying is also recognised to raise other issues. As another respondent (P12) indicated ...some teachers have bullying practices against parents by not giving rewards to their children or not including their photographs in newsletters - but including their friends. In this example, a parent and child are victims of teacher bullying. This aspect is supported by another respondent (P8) who stated ...teachers lower the grades of my child just because he is a bully! It just isn't right.

It would appear that all modes of bullying have been used. However, threatening behaviour short of physical striking has been initiated in the classroom as well as in public (school playground and child pickup zones) - although most incidents in the past year appear to be verbal insults and relational in nature.

When asked in a follow-up question why parents engage in bullying behaviour the answers are not simply black and white. For example, one respondent (P2) indicated that ... as we pay for the child's tuition at the school, the teacher should defer to us parents. He doesn't. Another respondent (P6) further suggests that ... of course we come to this school rather than the Thai one. I pay the teachers salary. So he should accept what the parent's tell him. One respondent (P10) illustrates the depth of bullying at the school as ...the office appears to be the only safe place from bullying parents and even here they follow you in and they have to be told to leave.

\subsubsection{Gender Issues}

Gender issues were raised by parents as one respondent (P7) indicated ...women are worse than the male parents. But male parents are very aggressive - while the women parents tend to talk behind your back. However, the majority of discussions with teachers appeared from the evidence to be female, and only when that avenue did not match the parent's wishes did it escalate into a bullying issue. Supporting this, one respondent (P5) suggested that ...males seen discussing aggressively with the teacher of their child is very disturbing. 
This further suggests that females discuss their issues in private, whereas male parents tend to try to dominate even if it is in public. However, another respondent (P10) indicated that ...it may be in public because the teacher ignores the parent's in private. This is a problem here. Teachers hiding when they should be helping my child learn, instead of making excuses.

Second research question: How does bullying between teachers and parents affect other stakeholders in the school?

\subsubsection{Teaching Staff}

Teaching staff are central to the development of a learning environment for children. However, other stakeholders affect how this environment can be utilised effectively. For example, one respondent (P9) indicated that ...Oh the headmaster. He's a jerk. He sees what going on but just lets it happen. He's pathetic. This is reinforced by another respondent (P1) who stated .... and another point I want to raise, the headmaster doesn't take responsibility for any of this. He just sits in his office. He doesn't standup to what's right. Another respondent (P11) claimed that ...the school council and the head are at fault - no one can get to the school council to tell them what's happening - not even an acknowledgement from our letters. They are deaf. In light of this, one respondent (P2) suggested ...does this school really have a council? Why can't they help stop teacher bullying! Further, some parents expressed the notion, as typified by one respondent (P3) as ...some teachers are great. Others are just from the gutter, when they try to intimidate you to pay for extra equipment or even if you check why my child has received such a low grade. Another respondent (P7) who appears to be critical of teacher behaviour indicated ...teachers don't seem to want to supervise the playground after school because they just want to leave to go home as soon as possible. This aspect is supported by another respondent (P1) who stated that ...teachers don't seem to want to do playground duty and that's where lots of accidents happen at this school. However, some respondents appeared to be exacerbated with their child's teacher's behaviour. As one respondent ( $\mathrm{P} 4)$ indicated that ...even my child was reprimanded by a teacher for saying that an American spelling of a word was incorrect. Teachers not only bully parents but they also bully some children too.

One respondent (P5) raised the issue of teacher's responsibilities, who stated ...I have an issue with teachers who don't respond to my child's requests for help. You can't ignore violence at school. This is mirrored in some way, by another respondent (P7) who questioned ...why is it that I have to speak out - teachers and parents here ignore the subject rather than tackling it - especially the head.

\subsubsection{Other Parents}

Some parents showed some displeasure with other parent's behaviour. For example, one respondent (P5) reported that ...I sometimes feel... he walks in - all 5ft nothing and thinks that if he can't get what he wants he just goes into a rage. He's terrible. A real animal. The head does nothing to reduce parent-parent aggression (Johnson and Johnson, 1989). Another respondent (P8) indicated that ...this school sucks. It's cheap so it lets anyone in here! No quality. Some parents should be in a zoo. 
Some parents though carried out bullying and this issue is raised by another respondent (P10) ...some parents are just so silly. They think that trying to shove other parents will make it easier for their child in school. You've got to be kidding me! Another respondent (P5) indicated that ...because of them I cannot bring myself to come to the school, I'm afraid. Another aspect raised was - the sometimes public nature - of bullying. As one respondent (P6) stated ...I have witnessed bullying between parents. It's not pretty. But it seems that it's always the same parents who bully in public - like they like the attention. Sad really.

On the notion of recommending the school, one respondent (P4) indicated ...no not really. Not to my worst enemy. This was also supported by another respondent (P9) who stated ...no. I cannot. Not from my experience.

Third research question: What policies need to developed and implemented to reduce bullying between teachers and parents?

\subsubsection{Policy Developments}

The school has a written policy on bullying - targeted to children's behaviour. However, as one respondent (P3) stated ...what's the point of having an anti-bullying week when the head doesn't stop it in plain sight between parents and teachers! Another respondent (P5) indicated that ...no parent-teacher bullying incident log was seen, nor was it anticipated that one would be developed. Since there were many parent-teacher incidents, then these should be recorded. It is as if the school-head wanted to hide the incidents of parent-teacher bullying at the school. Another respondent (P9) suggested that ...the school has an anti-bullying week every year, but little changes - does it?

\subsubsection{School Relationships}

School and community relationships appear to be an important aspect of school-life for parents. As one respondent (P3) indicated ...the school community expects a reduction in bullying, but the head doesn't see it that way. Another respondent (P2) suggested that ...the school hides behind it procedures. But y'know when my child was bullied and injured nothing was done - the bully didn't even get a reprimand. Further, another respondent (P12) indicated that ...there is something very wrong with the school when a desperate letter to WASC about excessive bullying patterns here goes unanswered. A major issue that was raised was the limited relationship beyond the head-teacher, as typified by one respondent (P6) who stated ...we cannot contact the school council. The head won't let us have access. What's wrong with talking to the body that manages the school!

The outcomes of assessing the 8 mitigation strategies considered to positively support the main/sub themes show school management requirements. Reporting on bullying between parents and teachers require also the need to understand what parents see as ways, means and methods to deal with the bullying practice - whether in a private or public place at the school. What methods do parent's see as useful to mitigate parent-teacher bullying? Similar issues can be raised for parents as for students. There would appear to be discrimination however, between how parents are treated and school teachers. For example, one respondent (P11) indicated that ...no parent is told if any teaching staff are disciplined. This means that they 


\section{Macrothink}

are independent and parents have no way to objectively see what management does about bullying or conflict situations. A bullying policy may provide a basis for school operations, but this alone is certainly not enough (Smith, et al., 2008). This also speaks clearly about the power of the parent - who ...pays the salaries of all staff at the school (P8) and yet do not appear ...to be listened to or to have any real influence in the school management (P2). What parents can offer to reduce parent-teacher bullying - the major indications are contained in Figure 1, below.

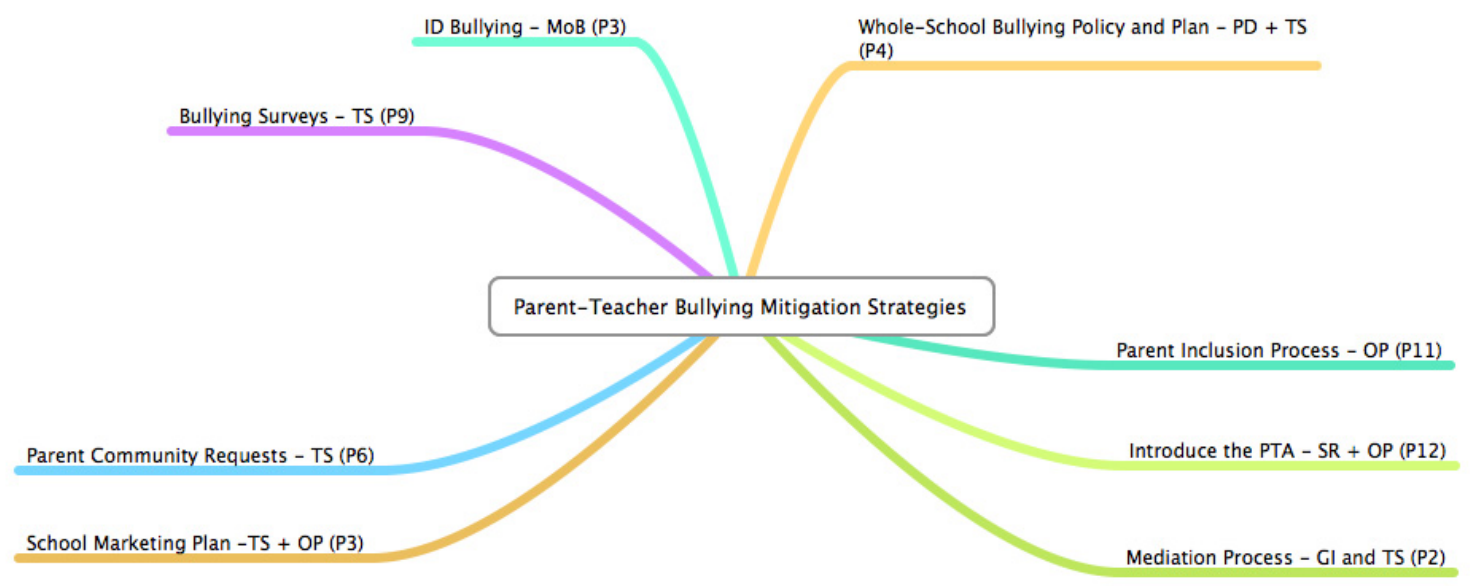

Figure 1. Parent-Teacher Bullying Mitigation Strategies

The research outcomes are presented in Figure 2, below:

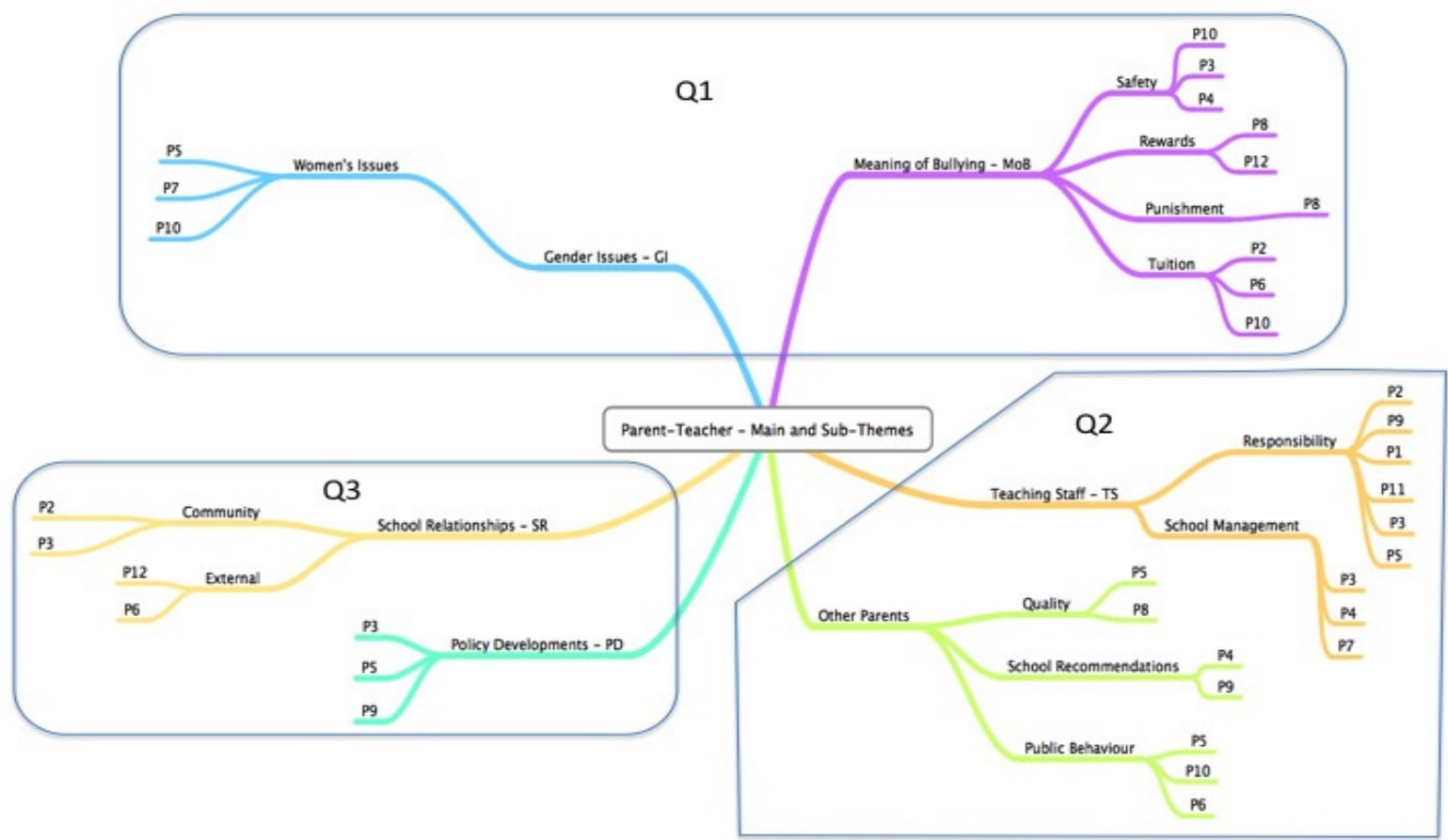

Figure 2. Parent-Teacher - Main and Sub-theme Outcomes 
Out of 293 coding snippets, Figure 2, above, underpins the major outcomes as - Q1 - 11; Q2 - 16; and Q3 - 7 which are considered appropriate and context sensitive. Figure 1, also illustrates the derived relationships between the major themes illustrating parent's views regarding parent-teacher bullying practices. The model further shows the conceptual development and relationships perceived to correspond to the features to possibly inform school policy which allows school management to focus on how these influence their strategic perceptions and intentions. Figure 1, above also shows 8 mitigation strategies that were offered by parents as ways to help reduce bullying between parents and teachers.

\section{Discussion}

Parents appear to utilise a responsive and caring approach in an observable child-centred culture (Price, Arnould and Tierney, 1995) focusing on helping their children learn in a diversified school environment. The evidence does not appear to support the notion that the school provides a positive environment (Lockwood and Jones, 1989) that enhances the perceptions of parent-staff interactions during school-based encounters (Smith, Bolton and Wagner, 1999). As such, parents appear to support the outcomes in terms of the mediating requirements to reduce parent-teacher bullying-related stress and confusion. The evidence further suggests that school managers do not listen to parents or provide an appropriate pattern of service provision (Bitner, 1992) relevant to their particular needs - which complements similar outcomes reported elsewhere (Fry, Humphreys and Francis, 1998) when using benchmarking techniques in services. This would be particularly important if large numbers of international parents and their children attend the school in the future. Parents recommendations in terms of mediating strategies are further discussed below.

This discussion continues with a direct appraisal of the research questions.

First research question: In what ways and forms is teacher-parent bullying characterised at this school? Parents views of the meaning of bullying varied but followed a similar pattern of exposure and outcome - requiring safety, and to deal with inappropriate rewards, punishment and tuition issues. Threatening behaviour short of physical striking has been initiated in the classroom as well as in public (school playground and child pickup zones) although most incidents in the past year appear to be verbal insults and relational in nature. Gender was shown as an area that raised significant issues, as males appeared to be more aggressive than females. This situation is an interesting outcome, as most teachers are males, and most parents having day-to-day connections with the school are female and may indicate the perception that teachers may complicate (Bradshaw, Sawyer and O'Brennan, 2007) bullying issues.

Second research question: How does bullying between teachers and parents affect other stakeholders in the school?

Teaching staff appeared to be resilient to parents suggestions which could be characterised as dispute-related aggression (Felson and Tedeschi, 1993) as this may reflect the autonomous nature of their perceived teaching responsibilities and undermine any bullying prevention scheme (Bradshaw, Sawyer and O'Brennan, 2007). This further creates 
issues with the lack of responsibility by the head-teacher and the use of an authoritarian approach to school management (Einarsen, 1999). For example - mirroring Brodsky (1976) who shows the reasons for the occurrence of bullying to be an excessive top-down approach to managing the school which may erupt into visible personalised conflicts (Kaye, 1994).

Other parents appear to be concerned with the visible nature of bullying (Bjorkqvist, Osterman and Hjelt-Back, 1994a) between teacher and parent and is further perceived as a negative influence on school management capabilities. Accordingly, parental participation in bullying prevention (Cunningham et al., 2009) maybe seen as a precautionary requirement.

Third research question: What policies need to developed and implemented to reduce bullying between teachers and parents?

School relationships appear to be stretched as the head-master prefers a single hands-on process that leaves parents dissatisfied and frustrated; with some parents recognising that some individualistic teachers and parents appear to have high levels of psychological pathology (Johnson and Johnson, 1989) and tend to provoke aggression in others (Einarsen, Raknes and Matthiesen, 1994a).

Policy development and their application appears to be inadequate in the view of parents - especially in the area of parent-teacher bullying and therefore its importance of reduction maybe misunderstood (Farrington and Ttofi, 2009).

The parent perception of an enhanced proactive school process stance indicates how parents perceptions of bullying are influenced by the response from the school management and its environment (Fry, Humphreys and Francis, 1998). Complaints appeared to be a source for learning for the school management as complaints are necessary (Tax and Brown, 1998) and provides further support for the development of good school relationships (Ahluwalia, Unnava and Burnkrant, 1999) through the consideration and development of bullying mitigation strategies.

The bullying mediation strategies suggested by parents in Figure 1, above (S3.1.6) outline a focused understanding of the ways for managing bullying e.g. Mediation by peers (Cowie, 2000) in order to reduce victimisation (Cowie, et al., 1994); Involve parents by making bullying by teachers accountable to a PTA sub-group - Based on Limper (2000); Develop a proper bullying plan that includes how teachers are going to be reprimanded reflecting a bullying zero-tolerance approach (Garbarino 2004) and positing more comprehensive requirements than those adopted for students (Vaillancourt et al., 2008). Parent perception of bullying whilst in the public domain reinforced bullying issues (O'Connell, Pepler and Craig, 1999) that continued or was conducted in private. The importance of identifying improvement mechanisms for reducing bullying (Farrington and Ttofi, 2009) has been highlighted by parents through their indications of the mitigating strategies. However, although these may sensible in nature they can only help in the reduction of bullying that appears to be endemic at this school and require much more investment in support and training (Cunningham et al., 2009). 
Mediation strategies suggested by parents appear to be very contextual in nature reflecting wide-experiences of bullying between teacher and parent that not only indicate that parents want bullying minimized, but that they also have searched ways to reduce it. This suggests that parents want peace at the school and that the school management need to listen to them in order to provide a positive environment for learning, working and the development of a inclusive school community.

\section{Conclusions}

It is essential to develop a climate that offers emotional and social support to all members of the school community (Cowie \& Colliety, 2010). The evidence presented here suggests that parents have negative experiences regarding bullying parents and teachers. Parent's experiences may explain how inadequate the school management's response was and appeared to reinforce parent perceptions of lack of control and the mismanagement of the school.

\section{Limitations}

As a study closely tied to a single school, generalizations cannot therefore be made. The approach using a qualitative methodology should not be seen as a limitation as the intention was to peel away very personal perceptions and issues and for some this was difficult. Influence on the outcomes could also be attributed to the focus of the research topic as parents may have "let off stream" in order to voice their views. Elsewhere, these views need to be explored further at other schools in Thailand in order to ensure that parent views are tested and taken into consideration when developing improved school management systems and its management through responses to competitive forces and highlighting the increasing importance of the parent voice in the school community.

\section{References}

Ahluwalia, R.H., Unnava, R., \& Burnkrant, R.E. (1999). Towards understanding the value of a loyal customer: an information processing perspective (Report No. 99-116). Cambridge, MA: Marketing Science Institute.

Baldry, A.C., \& Farrington, D.P. (2000). Bullies and delinquents: Personal characteristics and parental styles. Journal of Community and Applied Social Psychology, 10(1), 17-31. http://dx.doi.org/10.1002/(SICI)1099-1298(200001/02)10:1<17::AID-CASP526>3.0.CO ;2-M

Balshem, M. (1991). Cancer, control and causality: Talking about cancer in a working-class community. American Ethnologist, 18(1), 152-172. http://dx.doi.org/10.1525/ae.1991.18.1.02a00070

Barboza, G.E., Schiamberg, L.B., Oehmke, J., Korzeniewski, S.J., Post, L.A., \& Herauz, C.G. (2009). Individual characteristics and the multiple contexts of adolescent bullying: An ecological perspective. Journal of Youth and Adolescence, 38(1), 101-121. http://dx.doi.org/10.1007/s10964-008-9271-1 
Bauman, S. (2008). The role of elementary school counselors in reducing school bullying. The Elementary School Journal, 108(5), 362-375. http://dx.doi.org/10.1086/589467

Bauman, S., \& Del Rio, A. (2006). Pre-service teachers' response to bullying scenarios: Comparing physical, verbal, and relational bullying. Journal of Educational Psychology, 98(1), 219-231. http://dx.doi.org/10.1037/0022-0663.98.1.219

Benn, N., Buckingham, S., Domingue, J., \& Mancini, C. (2008). Ontological Foundations for Scholarly Debate Mapping Technology. In: 2nd International Conference on Computational Models of Argument (COMMA '08); 28-30 May, Toulouse, France.

Berthold, K.A., \& Hoover, J.H. (2000). Correlates of bullying and victimization among intermediate students in the Midwestern USA. School Psychology International, 21(1), 65-78. http://dx.doi.org/10.1177/0143034300211005

Bitner, M.J. (1992). Servicescapes: the impact of physical surroundings on customers and employees. Journal of Marketing, 56(2), 57-71.

Bjorkqvist, K., Osterman, K., \& Hjelt-Back, M. (1994a). Aggression among university employees. Aggressive Behavior, 20(3), 173-184. http://dx.doi.org/10.1002/1098-2337(1994)20:3<173::AID-AB2480200304>3.0.CO;2-D

Bosworth, K., Espelage, D.L., \& Simon, T.R. (1999). Factors associated with bullying behavior in middle school students. Journal of Early Adolescence, 19(3), 341-362. http://dx.doi.org/10.1177/0272431699019003003

Boulton, M.J. (2008). Pupils' perceptions of bullying and disruptions to concentration and attention to school work. Pastoral Care in Education, 26(2), 83-89. http://dx.doi.org/10.1080/02643940802062592

Bradshaw, C.P., Sawyer, A.L., \& O’Brennan L.M. (2007). Bullying and peer victimization at school: Perceptual differences between students and school staff. School Psychology Review, 36(3), 361-382. http://www.nasponline.org/publications/spr/index.aspx?vol=36\&issue=3

Brodsky, C. (1976). The Harassed Worker. Lexington Books, Washington, DC, US.

Buston, K. (1999). NUD*IST in action: its use and its usefulness in a study of chronic illness in young people. In Bryman A., \& Burgess R.G. (Eds.) Analysis and Interpretation of Qualitative Data. London: Sage Publications (pp.183-202).

Carman, J.M. (1990). Consumer perceptions of service quality: An assessment of the SERVQUAL dimensions. Journal of Retailing, 66(1), 33-55. http://dx.doi.org/10.1016/S0148-2963(99)00084-3

Carroll, L.J., \& Rothe, J.P. (2010). Levels of reconstruction as complementarity in mixed methods research: A social theory-based conceptual framework for integrating qualitative and quantitative research. International Journal of Environmental Research and Public Health, 7(9), 3478-3488. http://dx.doi.org/10.3390/ijerph7093478 
Cassell, C., \& Symon, G. (2004). Essential Guide to Qualitative Methods in Organizational Research. London: Sage Publications, UK.

Cayla, J., \& Eckhardt G.M. (2007). Asian brands without borders: regional opportunities and challenges. International Marketing Review, 24(4), 444-456. http://dx.doi.org/10.1108/02651330710761017

Conners-Burrow, N. A., Johnson, D. L., Whiteside-Mansell, L., McKelvey, L., \& Gargus, R.A. (2009). Adults matter: Protecting children from the negative impacts of bullying. Psychology in the Schools, 46(7), 593-604. http://dx.doi.org/10.1002/pits.20400

Cowie, H. (2000). Bystanding or standing by: Gender issues in coping with bullying in English schools. Aggressive Behavior, 26(1), 85-97. http://dx.doi.org/10.1002/(SICI)1098-2337(2000)26:1<85::AID-AB7>3.0.CO;2-5

Cowie, H., \& Colliety, P. (2010). Cyberbullying: sanctions or sensitivity? Pastoral Care in Education. An International Journal of Personal, Social and Emotional Development, 28(4), 261-268. http://dx.doi.org/10.1080/02643944.2010.528017

Cowie, H., \& Jennifer, D. (2007). Managing violence in schools: a whole-school approach to best practice. London, Paul Chapman; UK.

Cowie, H., \& Oztug, O. (2008). Pupils' perceptions of safety at school. Pastoral Care in Education, 26(2), 59-67. http://dx.doi.org/10.1080/02643940802062501

Cowie, H., Smith, P.K., Boulton, M.J., \& Laver, R. (1994). Co-operative group work in the multiethnic classroom. London: David Fulton, UK.

Craig, W., \& Pepler, D. (1997). Observations of bullying and victimization in the schoolyard. Canadian Journal of School Psychology, 13(2), 41-60. http://dx.doi.org/10.1177/082957359801300205

Craig, W., Pepler, D., \& Blais, J. (2007). Responding to bullying: What works? School Psychology International, 28(4), 465-477. http://dx.doi.org/10.1177/0143034307084136

Cunningham, C. E., Vaillancourt, T., Rimas, H., Deal, K., Cunningham, L. J., Short, K., \& Chen, Y. (2009). Modeling the bullying prevention program preferences of educators: A discrete choice conjoint experiment. Journal of Abnormal Child Psychology, 37(7), 929-943. http://dx.doi.org/10.1007/s10802-009-9324-2.

Delfabbro, P., Winefield, T., Trainor, S., Dollard, M., Anderson, S., Metzer, J., \& Hammarstrom, A. (2006). Peer and teacher bullying/victimization of South Australian secondary school students: Prevalence and psychosocial profiles. British Journal of Educational Psychology, 76(1), 71-90. http://dx.doi.org/10.1348/000709904X24645

Einarsen, S. (1999). The nature and causes of bullying at work. International Journal of Manpower, 20(1/2), 16-27. http://dx.doi.org/10.1108/01437729910268588.

Einarsen, S., Raknes, B.I., \& Matthiesen, S.M. (1994a). Bullying and harassment at work and their relationships to work environment quality - an exploratory study. European Work 
and

http://dx.doi.org/10.1080/13594329408410497

Ellis, A.A., \& Shute, R. (2007). Teacher responses to bullying in relation to moral orientation and seriousness of bullying. British Journal of Educational Psychology, 77(3), 649-663. http://dx.doi.org/10.1348/000709906X163405

Espelage, D.L., \& Swearer, S.M. (2003). Research on school bullying and victimization: What have we learned and where do we go from here? School Psychology Review, 32(3), 365-383.

Farrington, D.P., \& Ttofi, M.M. (2009). School-based programs to reduce bullying and victimization. Campbell Systematic Reviews, 6. http://dx.doi.org/10.4073/ csr.2009.6

Fekkes, M., Pijpers, F.I.M., \& Verloove-Vanhorick, S.P. (2005). Bullying: Who does what, when, and where? Involvement of children, teachers, and parents, in bullying behavior. Health Education Research, 20(1), 81-91. http://dx.doi.org/10.1093/her/cyg100

Felson, R.B., \& Tedeschi, J.T. (1993). Aggression and Violence: Social Interactionst Perspectives. American Psychological Association, Washington, DC, US.

Flaspohler, P.D., Elfstrom, J.L., Vanderzee, K.L., Sink, H.E., \& Birchmeier, Z. (2009). Stand by me: The effects of peer and teacher support in mitigating the impact of bullying on quality of life. Psychology in the Schools, 46(7), 636-649. http://dx.doi.org/10.1002/pits.20404

Fleming, L.C., \& Jacobsen, K.H. (2009). Bullying and symptoms of depression in Chilean middle school students. Journal of School Health, 79(3), 130-137. http://dx.doi.org/10.1111/j.1746-1561.2008.0397.x

Fry, J., Humphreys, I., \& Francis, G. (2005). Benchmarking in civil aviation: some empirical evidence. Benchmarking: An International Journal, 12(2), 125-137. http://dx.doi.org/10.1108/14635770510593077

Garbarino, J., \& deLara E. (2002). And words can hurt forever: How to protect adolescents from bullying, harassment, and emotional violence. New York, NY: The Free Press, US.

Garbarino, J.G. (2004). Foreword. In Bullying in American schools: A social-ecological perspective on prevention and intervention, D.L. Espelage and S.M. Swearer, (Eds.). xi-xiii. Mahwah, NJ: Lawrence Erlbaum, US.

Germain, C.B., \& Bloom, M. (1999). Human behavior in the social environment: An ecological view (Second Edition). New York: Columbia University Press, US.

Gilgun, J.F., \& Abrams, L.S. (2002). The nature and usefulness of qualitative social work research. Qualitative Social Work, 1(1), 39-55. http://dx.doi.org/10.1177/1473325002001001743

Glaser, B.G. (1992a). Basics of grounded theory analysis: Emergence vs. forcing. Mill Valley, CA: Sociology Press, US. 
Glaser, B.G. (2004). Remodeling Grounded Theory. The Grounded Theory Review: An international Journal, 4(1), November, Sociology Press, USA.

Glaser, B.G., \& Strauss, A.L. (1967). The Discovery of Grounded Theory: Strategies for qualitative research. Chicago: Aldine, US.

Gonzalez, C. (2008). Conceptions of, and approaches to, teaching online: a study of lecturers teaching postgraduate distance courses. Higher Education, 57(3), 299-314. http://dx.doi.org/10.1007/s10734-008-9145-1

Gray, J., \& Wilcox, B. (1995). Good Schools, Bad Schools. Open University Press, UK.

Harel-Fisch, Y., Walsh, S. D., Fogel-Grinvald, H., Amitai, G., Pickett, W., \& Molcho, M. et al. (2010). Negative school perceptions and involvement in school bullying: A universal relationship across 40 countries. Journal of Adolescence, 34(4), 639-652. http://dx.doi.org/10.1016/j.adolescence.2010.09.008

Harrel, G.D., \& Fors, M.F. (1995). Marketing services to satisfy internal customers. Logistics Information Management, 8(4), 22-27. http://dx.doi.org/10.1108/09576059510091887

Harwood, T.G., \& Garry, T. (2003). An overview of content analysis. The Marketing Review, 3(4), 479-498. http://dx.doi.org/10.1362/146934703771910080

Hawley, P.H. (1999). The ontogenesis of social dominance: A strategy-based evolutionary $\begin{array}{llll}\text { perspective. Developmental } & \text { Review, }\end{array}$ http://dx.doi.org/10.1006/drev.1998.0470

Johns, C.J., Livson, N., \& Peskin, H. (2003). Longitudinal hierarchical linear modeling analyses of California psychological inventory data from age 33 to 75: An examination of stability and change in adult personality. Journal of Personality Assessment, 80(3), 294-308. PubMed: 12763702. http://dx.doi.org/10.1016/j.jrp.2005.09.006

Johnson, D.W., \& Johnson, R.T. (1989). Cooperation and competition: Theory and research. Edina, MN: Interaction; US.

Kaye, K. (1994). Workplace Wars and How to End Them. Turning Personal Conflicts into Productive Teamwork. Amacom, New York, NY, US.

Limper, R. (2000). Cooperation between parents, teachers, and school boards to prevent bullying in education: An overview of work done in the Netherlands. Aggressive Behaviour, $26(1)$,

125-134. http://dx.doi.org/10.1002/(SICI)1098-2337(2000)26:1<125::AID-AB10>3.0.CO;2-7

Lockwood, A., \& Jones P. (1989). Creating Positive Service Encounters. The Cornell H.R.A. Quarterly, 29(4), 44-50. http://dx.doi.org/10.1016/j.bbr.2011.03.031

Maunder, R., Harrop, A., \& Tattersall, A. (2010). Pupil and staff perceptions of bullying in secondary schools: Comparing behavioural definitions and their perceived seriousness. Educational

263-282. http://dx.doi.org/10.1080/00131881.2010.504062 
Mishna, F., \& Alaggia, R. (2005). Weighing the risks: A child's decision to disclose peer victimization. Children \& Schools, 27(4), 217-226.

Nansel, T.R., Overpeck, M., Pilla, R.S., Ruan, W.J., Simons-Morten, B., \& Scheidt, P. (2001). Bullying behaviors among US youth: Prevalence and association with psychosocial adjustment. JAMA, 285(16), 2094-2100. http://dx.doi.org/10.1001/jama.285.16.2094

Nordhagen, R., Nielsen, A., Stigum, H., \& Kohler, L. (2005). Parental reported bullying among Nordic children: A population-based study. Child: Care, Health and Development, 31(6), 693-701. http://dx.doi.org/10.1111/j.1365-2214.2005.00559.x

O’Connell, P., Pepler, D. J., \& Craig, W. (1999). Peer involvement in bullying: Insights and challenges for intervention. Journal of Adolescence, 22(4), 437-452. http://dx.doi.org/10.1006/jado.1999.0238

Olweus, D. (1993). Bullying at school: What we know and what we can do. Oxford: Blackwell, UK.

Powell, H. S., Mihalas, A.J., Onwuegbuzie, S., Suldo P., \& Daley, C.E. (2008). Mixed methods research in school psychology: A mixed methods investigation of trends in the literature. Psychology in the Schools, 45(4), 291-308. http://dx.doi.org/10.1002/pits.20296

Price, L., Arnould, E., \& Tierney, P. (1995). Going to extremes: managing service encounters and assessing provider performance. Journal of Marketing, 59(2), 83-97. http://www.jstor.org/stable/1252075

Reeves, T.K., \& Harper, D. (1981). Surveys at Work. London: McGraw-Hill, UK.

Reisman, C.K. (1993). Narrative Analysis. London: Sage Publications, UK.

Rivers, I. (2001). Retrospective reports of school bullying: Stability of recall and its implications for research. British Journal of Developmental Psychology, 19(1), 129-141. http://dx.doi.org/10.1348/026151001166001

Sawyer, J.L., Mishna, F., Pepler, D., \& Wiener, J. (2011). The missing voice: Parents' perspectives of bullying. Children and Youth Services Review, 33(10), 1795-1803. http://dx.doi.org/10.1016/j.childyouth.2011.05.010

Seeds, P.M., Harkness, K.L., \& Quilty, L.C. (2010). Parental maltreatment, bullying, and adolescent depression: Evidence for the mediating role of perceived social support. Journal of Clinical Child and Adolescent Psychology, 39(5), 681-692. PubMed: 20706920. http://dx.doi.org/10.1080/15374416.2010.501289

Smith, A.K., Bolton, R.N., \& Wagner, J. (1999). A model of customer satisfaction with service encounters involving failure and recovery. Journal of Marketing Research, 36(3), 356-372. http://www.jstor.org/stable/3152082

Smith, P.K., \& Shu, S. (2002). What good schools can do about bullying: Findings from a survey in English schools after a decade of research and action. Childhood, 7(2), 
193-212. http://dx.doi.org/10.1177/0907568200007002005

Smith, P.K., Pepler, D.J., \& Rigby, K. (Eds.). (2004). Bullying in schools: How successful can interventions be? Cambridge, UK: Cambridge University Press, UK.

Smith, P.K., Smith, C., Osborn, R., \& Samara, M. (2008). A content analysis of school anti-bullying policies: Progress and limitations. Educational Psychology in Practice, 24(1), 1-12. http://dx.doi.org/10.1080/02667360701661165

Strauss, A.L., \& Corbin, J. (1990). Basics of qualitative research: Grounded theory, procedures and techniques. Newbury Park: Sage Publications, US.

Sullivan, K. (2000). The anti-bullying handbook. Auckland, New Zealand: Oxford University Press, NZ.

Tax, S.S., \& Brown, S.W. (1998). Recovering and Learning from Service Failure. Sloan Management Review, 40(1), 75-89.

Torrance, D.A. 2000. Qualitative studies into bullying within special schools. British Journal of Special Education, 27(1), 16-21. http://dx.doi.org/10.1111/1467-8527.t01-1-00151

Tull, D.S., \& Hawkins, D.I. (1990). Marketing Research: Measurement and Method. Macmillan, UK.

Vaillancourt, T., McDougall, P., Hymel, S., Krygsman, A., Miller, J., \&Stiver, K. et al., (2008). Bullying: Are researchers and children/youth talking about the same thing? International Journal of Behavioural Development, 32(6), 502-511. http://dx.doi.org/10.1177/0165025408095553

Walsh, S.P., White, K.M., \& Young, R.M. (2008). Over-connected? A qualitative exploration of the relationship between Australian youth and their mobile phones. Journal of Adolescence, 31(1), 77-92. http://dx.doi.org/10.1016/j.adolescence.2007.04.004

Wang, J., Iannotti, R. J., \& Nansel, T. R. (2009). School bullying among adolescents in the United States: Physical, verbal, relational and cyber. The Journal of Adolescent Health, 45(4), 368-375. http://dx.doi.org/10.1016/j.jadohealth.2009.03.021

Whitney, I., \& Smith, P.K. (1993). A survey of the nature and extent of bully/victim problems in junior/middle and secondary schools. Educational Research, 35(1), 3-25. http://dx.doi.org/10.1080/0013188930350101

\section{Copyright Disclaimer}

Copyright reserved by the author(s).

This article is an open-access article distributed under the terms and conditions of the Creative Commons Attribution license (http://creativecommons.org/licenses/by/3.0/). 